\title{
Toronto Alexithymia Scale: Adaptation of the Brazilian Version to Low-Educated Adults ${ }^{1}$
}

\author{
Tatiana Roccato Fortes \\ Universidade Federal de São Paulo, \\ São Paulo-SP, Brazil
}

\author{
Isabel Altenfelder Santos Bordin \\ Universidade Federal de São Paulo, \\ São Paulo-SP, Brazil
}

\author{
Norma Lottenberg Semer \\ Universidade Federal de São Paulo, \\ São Paulo-SP, Brazil
}

\begin{abstract}
For the purpose of studying Alexithymia in low-educated adults, we intend to adapt the Brazilian version of the Toronto Alexithymia Scale (TAS-26) and to verify its internal consistency. With that aim, we translated the original TAS-26 (English) to Portuguese, adopting a colloquial language, without content distortion. An exploratory qualitative study interviewed 50 women (38-65 years, education $<9$ years) and identified comprehension difficulties in 22 items, that needed adaptation. A professional translator performed the back-translation of the adapted TAS-26, that was applied to a new sample of women (90 with chronical pain and 90 without pain, 38-65 years, education $<9$ years) to evaluate its internal consistency. Only four items $(1 / 2 / 3 / 16)$ of the pre-existing Brazilian version (appropriate to university students) did not require modification. The internal consistency (Cronbach's alpha) was satisfactory for total score ( 0.65$)$ and elevated for factor 1 (0.87). The adapted Brazilian version of TAS-26 is appropriate to low-educated adults.
\end{abstract}

Keywords: alexithymia, educational status, scales, qualitative research, psychometrics

\section{Toronto Alexithymia Scale: Adaptação da Versão Brasileira para Adultos de Baixa Escolaridade}

\begin{abstract}
Resumo: Com objetivo de estudar a alexitimia em indivíduos adultos de baixa escolaridade, decidimos adaptar a versão brasileira da Toronto Alexithymia Scale (TAS-26) e verificar sua consistência interna. Para isso, traduzimos a TAS-26 original (inglês) para o português, com linguagem coloquial, sem alteração de conteúdo. Em estudo exploratório qualitativo foram entrevistadas 50 mulheres (38-65 anos, escolaridade $<9$ anos) e identificamos dificuldade de compreensão em 22 itens, que necessitaram de adaptação. Após retro-tradução feita por tradutor profissional, a TAS-26 adaptada foi então aplicada a nova amostra de mulheres (90 com dor crônica e 90 sem dor, 38-65 anos, escolaridade $<9$ anos) para avaliar sua consistência interna. Apenas quatro itens (1/2/3/16) da versão brasileira pré-existente (apropriada a universitários) não sofreram modificação. A consistência interna (alfa de Cronbach) foi satisfatória na pontuação total $(0,65)$ e elevada no fator $1(0,87)$. A versão brasileira da TAS-26 adaptada é adequada a indivíduos adultos de baixa escolaridade.
\end{abstract}

Palavras-chave: alexitimia, escolaridade, escalas, pesquisa qualitativa, psicometria

\section{Toronto Alexithymia Scale: Adaptación de la Versión Brasileña para Adultos con Baja Escolaridad}

\begin{abstract}
Resumen: Con objeto de estudiar la Alexitimia en adultos con bajo nivel de educación, buscamos adaptar la versión brasileña de la Escala de Alexitimia de Toronto (TAS-26) y comprobar su consistencia interna. Para esto, traducimos la TAS-26 original (inglés) al portugués, con la adopción de un lenguaje sencillo, sin cambiar el contenido. Una encuesta cualitativa entrevistó a 50 mujeres (38-65 años, escolaridad $<9$ años) e identificamos dificultad de comprensión sobre 22 puntos, que demandaron adaptaciones. Tras la retro-traducción por un traductor profesional, la TAS-26 adaptada fue aplicada a una nueva muestra de mujeres (90 con dolor crónico y 90 sin dolor, 38-65 años, escolaridad $<9$ años) para evaluar su consistencia interna. Sólo cuatro ítems (1/2/3/16) de la versión brasileña preexistente (apropiada para universitarios) no fueron cambiados. La consistencia interna (alfa de Cronbach) fue satisfactoria en la puntuación total $(0,65)$ y alta en el factor $1(0,87)$. La versión brasileña de la TAS-26 adaptada es adecuada para adultos con bajo nivel de escolaridad.
\end{abstract}

Palabras clave: alexitimia, escolaridad, escalas, investigación cualitativa, psicometría

\footnotetext{
${ }^{1}$ Article derived from the first author's master's dissertation, under supervision of the second and third authors, defended in 2015 in the Graduate Program in Psychiatry and Medical Psychology at the Universidade Federal de São Paulo. Support: Master's dissertation scholarship in the Coordination for the Improvement of Higher Education Personnel (CAPES)

${ }^{2}$ Correspondence address:

Tatiana Roccato Fortes. Departamento de Psiquiatria, Universidade Federal de São Paulo, Escola Paulista de Medicina. Rua Borges Lagoa, 570, Vila Clementino. CEP: 04038-000. São Paulo-SP, Brazil. E-mail: tatianaroccato@ gmail.com
}

The first reports of patients who experience difficulties describing feelings, distinguishing between feelings and bodily sensations and have a concrete and experienced-based cognitive style (Taylor, Bagby, \& Parker, 2003a), as well as lack of empathy (Swart, Kortekaas, \& Aleman, 2009; Di Tella \& Castelli, 2016), emerged at the end of the 1940s. The term alexithymia was coined in 1972 by Sifneos to describe patients with these difficulties who do not meet the psychotherapy 
eligibility criteria (Bagby, Parker, \& Taylor, 1994; Praceres, Parker, \& Taylor, 2000; Sfineos, 1973; Yoshida, 2000).

Alexithymia has been found in patients suffering chronic pain with no identifiable cause, including patients with fibromyalgia (van Middendorp et al., 2008), depression and psychosomatic illnesses (Kusevic et al., 2013), high blood pressure, Crohn's disease, psychiatric patients (panic and anxiety disorders, depression), and those with kidney and rheumatic diseases (Marchesi et al., 2013; Sayar, Kirmayer, \& Taillefer, 2004; Silva, Freitas, Moreira, Santos, \& Almeida, 2016; Di Tella \& Castelli, 2016). However, the prevalence of alexithymia has also been found to be as high as 7\% among the general population (Steinweg, Dallas, \& Rea, 2011) without any link to specific disorders (Cox, Kuch, Parker, Shulman, \& Evans, 1994; Praceres et al., 2000; Yoshida, 2000, 2007). It is known that the prevalence of fibromyalgia is greater among women (Hintistan, Cilingir, \& Birinci, 2013). A recent study involving patients suffering from chronic pain showed that pain and depression were more likely to get worse over time among those with alexithymia (Saariaho, Saariaho, Mattila, Joukamaa, \& Karukivi, 2016).

Statistics published by the Brazilian Institute of Geography and Statistics (Instituto Brasileiro de Geografia e Estatística) show that, in 2014, 12.4\% of Brazilians aged 15 and over had no schooling or less than one year of schooling and that $8.3 \%$ of the population was illiterate (IBGE, 2016). Studies have investigated the association between socioeconomic status, level of education and alexithymia (Carneiro \& Yoshida, 2009; Lumley, Stettner, \& Wehmer, 1996). However, there is a lack of alexithymia assessment instruments that are appropriately adapted for use with people with low levels of education. A study published in 2015 showed that people with low levels of education had more difficulty interpreting and responding a self-applied questionnaire on physical activity, which, as a result, was shown to lack adequate validity for use with this group. It is therefore reasonable to assume that the same occurs with personality scales, thus confirming the need to adapt tools for use with people with low levels of education (Winckers et al., 2015). Studies have shown that alexithymic characteristics increase with age, leading to more concrete and operative thinking (Hintistan et al., 2013), and that the lower the level of education the earlier alexithymic characteristics appear (Onor, Trevisiol, Spano, Aguglia, \& Paradiso, 2010).

A number of alexithymia assessment instruments were developed in the 1970s and 1980s. One of the most commonly used measures of alexithymia is the Toronto Alexithymia Scale (TAS), developed by Taylor, Ryan and Bagby in the 1980s (Bagby, Parker, et al., 1994; Bagby, Taylor, \& Parker, 1994; Praceres et al., 2000; Taylor, Bagby, \& Parker, 2003b; Wiethaeuper, Balbinotti, Pelisoli, \& Barbosa, 2005; Yoshida, 2000, 2007) as an alternative to instruments such as the Schalling-Sfineos Personality Scale and Beth Israel Hospital Psychosomatic Questionnaire, which had inadequate psychometric properties (Taylor et al., 1988, 2003b; Taylor, Ryan, \& Bagby, 1985). The TAS assesses five dimensions of the alexithymia construct: (1) difficulty describing feelings; (2) difficulty distinguishing between feelings and bodily sensa- tions; (3) lack of introspection; (4) social conformity; and (5) impoverished fantasy life and poor dream recall (Taylor et al, 1985, 2003a).

The TAS initially contained 41 items answered according to a five-point Likert scale: (1) strongly disagree, (2) somewhat disagree, (3) neither agree nor disagree, (4) somewhat agree, and (5) strongly agree. Of these 41 items, 25 were created by the authors, eight were derived from the Schalling-Sifneos Personality Scale (SSPS), four from the introspective awareness subscale of the Eating Disorder Inventory (Garner, Olmsted, \& Polivy, 1983), and four from the Need for Cognition Scale (Cacioppo \& Petty, 1982). These 16 items were revised so that they could be responded using the five-point Likert scale (Taylor et al., 2003a). Taylor et al. (1985) then administered this pilot scale to 542 undergraduate psychology students $(68.5 \%$ men) from two Canadian Universities. Following factor analysis, 26 items were retained (Taylor et al., 1985, 2003a).

Yoshida (2000) was the first person to develop a Brazilian version of the 26-item TAS (TAS-26), using a sample of 581 students (32.2\% men) aged between 17 and 52 years from a private university in the city of São Paulo. Factor analysis yielded four factors that were consistent with the alexithymia construct: Factor 1, comprising items 1, 3, 4, 8, 10, 14, 17, 20, $22,23,25$, and 26 associated with the ability to identify and describe feelings and distinguish between feelings and bodily sensations; Factor 2, comprising items 2, 5, 15, 16, and 18 associated with daydreaming; Factor 3, comprising items 7 , $9,11,13,19,21$, and 24, associated with externally-oriented thinking; and Factor 4, comprising items 6 and 12, associated with the ability to communicate feelings to other people (Yoshida, 2000, 2007).

The Center for Psychoanalytic and Pain Research and Therapy (Núcleo de Atendimento e Pesquisa em Psicanálise e Dor) provides psychotherapy to patients with painful conditions. This center is linked to the Department of Psychiatry at the Federal University of São Paulo (Departamento de Psiquiatria da Universidade Federal de São Paulo - UNIFESP), which, like other public health services in Brazil, provides various types of health care services to patients with a low level of education, including psychotherapy, physiotherapy, and nutritional counseling.

Psychotherapy aims to encourage the mentalization of somatic phenomena and promote a preference for thought content related to feelings, fantasies and other aspects of a person's inner world (Semer, 2012; Pirlot \& Corcos, 2012; Taylor, Bagby \& Parker, 2016). The assessment of the effectiveness of psychotherapy in reducing alexithymia and enhancing a patients' ability to identify and describe emotions requires appropriate assessment tools. Given that a significant proportion of public health service users have a low level of education, it is necessary to develop alexithymia assessment instruments that are appropriately adapted for use with this population group. In light of the lack of such instruments in Brazil, the present study seeks to adapt the Brazilian version of the TAS-26 for use with adults with low levels of education and measure the revised tool's internal consistency. 


\section{Method}

\section{Participants}

The sample comprised women aged between 38 and 65 years with between zero and eight years of formal schooling receiving treatment in the Fibromyalgia Outpatient Clinic of the Federal University of São Paulo (Ambulatório de Fibromialgia da Universidade Federal de São Paulo - UNIFESP) and a specialist outpatient clinic in the South Zone of the city of São Paulo.

\section{Instruments}

The 26-item Toronto Alexithymia Scale (TAS-26). The TAS-26 was developed to screen for the presence of alexithymia - the inability to distinguish between physical sensations and feelings, to describe emotions to others, and to symbolize (Taylor et al., 1985). The TAS-26 is a self-report measure of alexithymia and each item is responded using a five-point Likert scale: (1) strongly disagree, (2) somewhat disagree, (3) neither agree nor disagree, (4) somewhat agree, (5) strongly agree. The overall score can range from 26 to 130 and the following items are negatively keyed: $1,5,6,9,11,12,13,15$, 16,21 , and 24 . The following cut-off points were used for the overall score based on current literature: greater than or equal to 74 for the presence of alexithymia; less than or equal to 62 for absence of alexithymia; and between 63 and 73 for inconclusive (Carneiro \& Yoshida, 2009; Praceres et al., 2000; Taylor et al., 2003a; Yoshida, 2000, 2007).

\section{Procedure}

Data collection. To adapt the TAS-26 for use with Brazilian adults with a low level of education, the 26 items were translated from English to Portuguese, adopting a more colloquial language without changing the original content. Individual interviews were then conducted with 50 women aged between 38 and 65 years with less than nine years of schooling suffering from chronic pain and receiving treatment at a specialist outpatient clinic in the State of São Paulo. At the end of the qualitative study, the final Brazilian version was back translated by a professional translator.

All data was collected from the study participants by the same psychologist who administered individual interviews and the alexithymia scale.

The exploratory study was carried out in three stages: (1) investigation of the clarity of the items of the Brazilian version adapted for use with people with low levels of education in comparison to the existing Brazilian version used with university students to develop an initial adapted version; (2) assessment of understanding of the content of each item of the initial version to identify possible difficulties; and (3) reformulation of the items that presented understanding difficulties and assessment of understanding of the revised content of the items to elaborate the final adapted Brazilian version. Ten women participated in the first stage, 20 in the second stage, and 20 in the third stage. The following inclusion criteria were adopted: being a woman; being aged between 38 and 65 years; and having a low level of education (under nine years of schooling). Patients receiving medical treatment for pain were excluded from the study sample.

In stage 1, participants experienced difficulties in differentiating between the five response options of the Likert scale (strongly disagree, somewhat disagree, neither agree nor disagree, somewhat agree, strongly agree). The questionnaire was therefore modified (stages 2 and 3) presenting the response options as follows: agree, disagree, don't know; if the answer was "agree" or "disagree", the following question was asked - "totally" or "more or less"; if the answer was "don't know", the questionnaire asked whether the respondent had understood the item or whether she did not know whether to agree or not with the statement. In stage 2, the 20 women were divided into four groups of five as follows: aged between 38 and 50 years with zero to four years of schooling; aged between 38 and 50 years with five to eight years of schooling; aged between 51 and 65 years with zero to four years of schooling, and aged between 51 and 65 years with five to eight years of schooling. Stage 3 focused on older women with a lower level of education who may have greater difficulty in understanding the items: twenty women (17 aged between 51 and 65 years and three aged between 49 and 50 years) with between zero and four years of schooling were interviewed.

Data analysis. The internal consistency of the Brazilian version of the TAS-26 adapted for use with adults with low levels of education was measured using a sample of 180 adults: 90 patients suffering from chronic pain receiving treatment at the Fibromyalgia Outpatient Clinic of the Federal University of São Paulo and 90 not suffering from any pain complaint. The two groups were paired according to age (same age or one year difference) and level of education. The inclusion criteria were age between 38 and 65 years and less than nine years of schooling. It is important to note that this sample did not include any of the 50 women who participated in the qualitative exploratory study. Internal consistency was measured using Cronbach's alpha, considering both the overall score and the score obtained in the Factor 1 subscale (dificuldades em identificar os sentimentos e distingui-los das sensações físicas/ Difficulty identifying feelings and distinguishing between feelings and bodily sensations - DIF). The sample size $(n=180)$ afforded a power (probability of rejecting a null hypothesis) of $99.6 \%$ to detect the difference in Cronbach's alpha coefficient, where the null hypothesis value is 0.60 (poor consistency) (George \& Mallery, 2003) and the alternative hypothesis value of the adapted TAS-26 scale is 0.75 (acceptable level of consistency) (George \& Mallery, 2003), using the F-test with a significance level of 0.05 (probability of rejecting a true null hypothesis). Sample size calculations were performed using the PASS 2008 statistical software package (Power Analysis and Sample Size System - NCSS).

\section{Ethical Considerations}

The research project was approved by the Research Ethics Committee of the UNIFESP (application number 197.388), by the Research Ethics Committee of the City of São Paulo 
Health Department, by the Regional Health Coordinating Office Southeast (Coordenadoria Regional de Saúde Sudeste), and by the director of the specialist outpatient clinic, Dr. Alexandre Kalil Yasbeck. The coordinator of the Fibromyalgia Outpatient Clinic of the Federal University of São Paulo also consented to the study by signing a letter of agreement. The study participants also voluntarily agreed to take part in the study by signing an informed consent form.

\section{Results}

\section{Development of the Brazilian version of the adapted TAS-26}

Only four items of the existing Brazilian version of the TAS-26 did not require modifications (1, 2, 3, and 16) (Yoshi$\mathrm{da}, 2000$ ). Of the remaining 22 items that required modifications to facilitate understanding, five (items 7, 10, 11, 19, and 24) were reformulated in light of the difficulties observed in stage 2. Table 1 shows the final version of the Brazilian TAS26 adapted for use with adults with low levels of education.

Table 1

Toronto Alexithymia Scale: Brazilian version Adapted to Low-Educated Adults

\begin{tabular}{|c|c|c|c|c|c|c|}
\hline \multicolumn{7}{|c|}{ Responses } \\
\hline \multicolumn{2}{|r|}{$\begin{array}{c}\text { Items } \\
\text { Discordo Totalmente }\end{array}$} & \multirow{2}{*}{ 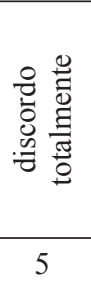 } & \multirow{2}{*}{ 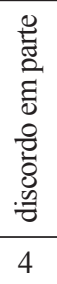 } & \multirow{2}{*}{ 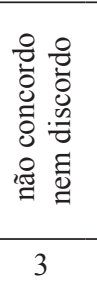 } & \multirow{2}{*}{ 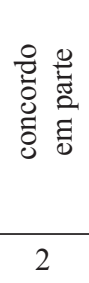 } & \multirow{2}{*}{ 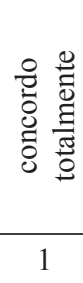 } \\
\hline 1 & Quando choro sempre sei por quê & & & & & \\
\hline 2 & "Sonhar acordado" é uma perda de tempo & 1 & 2 & 3 & 4 & 5 \\
\hline 3 & Gostaria de não ser tão tímido & 1 & 2 & 3 & 4 & 5 \\
\hline 4 & Muitas vezes fico confuso sobre qual emoção estou sentindo & 1 & 2 & 3 & 4 & 5 \\
\hline 5 & Muitas vezes fico sonhando acordado imaginando meu futuro & 5 & 4 & 3 & 2 & 1 \\
\hline 6 & Faço amigos tão facilmente quanto os outros & 5 & 4 & 3 & 2 & 1 \\
\hline 7 & $\begin{array}{l}\text { Quando eu tenho um problema, costumo achar uma solução sem pensar muito nos porquês } \\
\text { dessa solução }\end{array}$ & 1 & 2 & 3 & 4 & 5 \\
\hline 8 & É difícil para mim encontrar as palavras certas para falar sobre meus sentimentos & 1 & 2 & 3 & 4 & 5 \\
\hline 9 & Eu gosto de deixar claro para os outros o que eu penso das coisas & 5 & 4 & 3 & 2 & 1 \\
\hline 10 & O que eu sinto no corpo nem mesmo os médicos entendem & 1 & 2 & 3 & 4 & 5 \\
\hline 11 & Se alguma coisa foi feita para cumprir uma tarefa, eu preciso entender como essa coisa funciona & 5 & 4 & 3 & 2 & 1 \\
\hline 12 & Eu sou capaz de falar facilmente dos meus sentimentos & 5 & 4 & 3 & 2 & 1 \\
\hline 13 & Eu prefiro pensar sobre os problemas em vez de apenas falar deles & 5 & 4 & 3 & 2 & 1 \\
\hline 14 & Quando estou chateada, eu não sei se estou triste, assustada ou brava & 1 & 2 & 3 & 4 & 5 \\
\hline 15 & Uso bastante minha imaginação & 5 & 4 & 3 & 2 & 1 \\
\hline 16 & Fico um tempão sonhando acordado sempre que não tenho nada para fazer & 5 & 4 & 3 & 2 & 1 \\
\hline 17 & Muitas vezes fico confuso com as sensações do meu corpo & 1 & 2 & 3 & 4 & 5 \\
\hline 18 & Poucas vezes sonho acordado & 1 & 2 & 3 & 4 & 5 \\
\hline 19 & Quando as coisas acontecem não fico tentando entender por que elas aconteceram daquele jeito & 1 & 2 & 3 & 4 & 5 \\
\hline 20 & Eu tenho sentimentos que não consigo bem saber quais são & 1 & 2 & 3 & 4 & 5 \\
\hline 21 & Estar em contato com emoções é muito importante & 5 & 4 & 3 & 2 & 1 \\
\hline 22 & Eu acho difícil falar o que sinto em relação às pessoas & 1 & 2 & 3 & 4 & 5 \\
\hline 23 & As pessoas me pedem para falar mais sobre os meus sentimentos & 1 & 2 & 3 & 4 & 5 \\
\hline 24 & As pessoas deveriam procurar por explicações mais profundas das coisas & 5 & 4 & 3 & 2 & 1 \\
\hline 25 & Eu não sei o que acontece dentro de mim & 1 & 2 & 3 & 4 & 5 \\
\hline 26 & Muitas vezes não sei por que estou bravo & 1 & 2 & 3 & 4 & 5 \\
\hline
\end{tabular}

Note. In items $1,5,6,9,11,12,13,15,16,21$ and 24 the numbers corresponding to alternatives of response are inverted by recommendation of the author of the original TAS-26 
Table 2 shows three versions of the TAS-26: the original version (Taylor et al., 1985), the pre-existing Brazilian ver- sion used on university students (Yoshida, 2000), and the final version of the Brazilian TAS-26 adapted for use with adults with low levels of education.

Table 2

Three Versions of TAS-26: Original Version, Pre-Existing Brazilian Version (Applicable to University Students) and Adapted Brazilian Version (Applicable to Low-Educated Adults)

\begin{tabular}{|c|c|c|c|}
\hline & $\begin{array}{l}\text { Original version } \\
\text { (Taylor et al., 1985) }\end{array}$ & $\begin{array}{l}\text { Pre-existing version } \\
\text { (Yoshida, 2000) }\end{array}$ & $\begin{array}{c}\text { Adapted version } \\
\text { (authors of this study, 2015) }\end{array}$ \\
\hline 1 & When I cry I always know why & Quando choro sempre sei por quê & Quando choro sempre sei por quê \\
\hline 2 & Daydreaming is a waste of time & "Sonhar acordado" é uma perda de tempo & "Sonhar acordado" é uma perda de tempo \\
\hline 3 & I wish I were not so shy & Gostaria de não ser tão tímido & Gostaria de não ser tão tímido \\
\hline 4 & $\begin{array}{l}\text { I am often confused about what emo- } \\
\text { tion I am feeling }\end{array}$ & $\begin{array}{l}\text { Frequentemente fico confuso sobre qual } \\
\text { emoção eu estou sentindo }\end{array}$ & $\begin{array}{l}\text { Muitas vezes fico confuso sobre qual emoção es- } \\
\text { tou sentindo }\end{array}$ \\
\hline 5 & I often daydream about the future & $\begin{array}{l}\text { Frequentemente fico "sonhando acorda- } \\
\text { do" sobre o meu futuro }\end{array}$ & $\begin{array}{l}\text { Muitas vezes fico sonhando acordado imaginan- } \\
\text { do meu futuro }\end{array}$ \\
\hline 6 & $\begin{array}{l}\text { I seem to make friends as easily as oth- } \\
\text { ers do }\end{array}$ & $\begin{array}{l}\text { Pareço fazer amigos tão facilmente quan- } \\
\text { to as outras pessoas }\end{array}$ & Faço amigos tão facilmente quanto os outros \\
\hline 7 & $\begin{array}{l}\text { Knowing the answers to problems is } \\
\text { more important than knowing the rea- } \\
\text { sons for the answers }\end{array}$ & $\begin{array}{l}\text { Saber as respostas dos problemas é mais } \\
\text { importante do que saber as razões das } \\
\text { respostas }\end{array}$ & $\begin{array}{l}\text { Quando eu tenho um problema, costumo achar } \\
\text { uma solução sem pensar muito nos porquês dessa } \\
\text { solução }\end{array}$ \\
\hline 8 & $\begin{array}{l}\text { It is difficult for me to find the right } \\
\text { words for my feelings }\end{array}$ & $\begin{array}{l}\text { É difícil para mim encontrar as palavras } \\
\text { certas para os meus sentimentos }\end{array}$ & $\begin{array}{l}\text { É difícil para mim encontrar as palavras certas } \\
\text { para falar sobre meus sentimentos }\end{array}$ \\
\hline 9 & $\begin{array}{l}\text { I like to let people know where I stand } \\
\text { on things }\end{array}$ & $\begin{array}{l}\text { Eu gosto de mostrar às pessoas do que } \\
\text { preciso }\end{array}$ & $\begin{array}{l}\text { Eu gosto de deixar claro para os outros o que eu } \\
\text { penso das coisas }\end{array}$ \\
\hline 10 & $\begin{array}{l}\text { I have physical sensations that even } \\
\text { doctors don't understand }\end{array}$ & $\begin{array}{l}\text { Tenho sensações físicas que nem os mé- } \\
\text { dicos compreendem }\end{array}$ & $\begin{array}{l}\text { O que eu sinto no corpo nem mesmo os médicos } \\
\text { entendem }\end{array}$ \\
\hline 11 & $\begin{array}{l}\text { It's not enough for me that something } \\
\text { gets the job done; I need to know why } \\
\text { and how it works }\end{array}$ & $\begin{array}{l}\text { Para mim não é suficiente que as coisas } \\
\text { sejam feitas. Eu preciso saber por quê e } \\
\text { como elas funcionam }\end{array}$ & $\begin{array}{l}\text { Se alguma coisa foi feita para cumprir uma tare- } \\
\text { fa, eu preciso entender como essa coisa funciona }\end{array}$ \\
\hline 12 & I'm able to describe my feelings easily & $\begin{array}{l}\text { Sou capaz de descrever meus sentimen- } \\
\text { tos facilmente }\end{array}$ & $\begin{array}{l}\text { Eu sou capaz de falar facilmente dos meus sen- } \\
\text { timentos }\end{array}$ \\
\hline 13 & $\begin{array}{l}\text { I prefer to analyze problems rather than } \\
\text { just describe them }\end{array}$ & $\begin{array}{l}\text { Prefiro analisar problemas em vez de } \\
\text { apenas descrevê-los }\end{array}$ & $\begin{array}{l}\text { Eu prefiro pensar sobre os problemas em vez de } \\
\text { apenas falar deles }\end{array}$ \\
\hline 14 & $\begin{array}{l}\text { When I am upset, I don't know if I am } \\
\text { sad, frightened, or angry }\end{array}$ & $\begin{array}{l}\text { Quando estou chateado não sei se estou } \\
\text { triste, amedrontado ou com raiva }\end{array}$ & $\begin{array}{l}\text { Quando estou chateada, eu não sei se estou triste, } \\
\text { assustada ou brava }\end{array}$ \\
\hline 15 & I use my imagination a great deal & Uso um bocado minha imaginação & Uso bastante minha imaginação \\
\hline 16 & $\begin{array}{l}\text { I spend much time daydreaming when- } \\
\text { ever I have nothing else to do }\end{array}$ & $\begin{array}{l}\text { Fico um tempão sonhando acordado } \\
\text { sempre que não tenho nada para fazer }\end{array}$ & $\begin{array}{l}\text { Fico um tempão sonhando acordado sempre que } \\
\text { não tenho nada para fazer }\end{array}$ \\
\hline 17 & $\begin{array}{l}\text { I am often puzzled by sensations in my } \\
\text { body }\end{array}$ & $\begin{array}{l}\text { Frequentemente fico cismado com sensa- } \\
\text { ções em meu corpo }\end{array}$ & $\begin{array}{l}\text { Muitas vezes fico confuso com as sensações do } \\
\text { meu corpo }\end{array}$ \\
\hline 18 & I daydream rarely & Raramente sonho acordado & Poucas vezes sonho acordado \\
\hline 19 & $\begin{array}{l}\text { I prefer to just let things happen rather } \\
\text { than to understand why they turned out } \\
\text { that way }\end{array}$ & $\begin{array}{l}\text { Prefiro deixar as coisas acontecerem em } \\
\text { vez de entender por que elas acontecem } \\
\text { daquele jeito }\end{array}$ & $\begin{array}{l}\text { Quando as coisas acontecem não fico tentando } \\
\text { entender por que elas aconteceram daquele jeito }\end{array}$ \\
\hline 20 & $\begin{array}{l}\text { I have feelings that I can't quite iden- } \\
\text { tify }\end{array}$ & $\begin{array}{l}\text { Tenho sentimentos que mal posso iden- } \\
\text { tificar }\end{array}$ & $\begin{array}{l}\text { Eu tenho sentimentos que não consigo bem saber } \\
\text { quais são }\end{array}$ \\
\hline 21 & $\begin{array}{l}\text { Being in touch with emotions is essen- } \\
\text { tial }\end{array}$ & $\begin{array}{l}\text { Estar em contato com as emoções é es- } \\
\text { sencial }\end{array}$ & $\begin{array}{l}\text { Estar em contato com emoções é muito impor- } \\
\text { tante }\end{array}$ \\
\hline 22 & $\begin{array}{l}\text { I find it hard to describe how I feel } \\
\text { about people }\end{array}$ & $\begin{array}{l}\text { É difícil para mim descrever como me } \\
\text { sinto em relação às pessoas }\end{array}$ & $\begin{array}{l}\text { Eu acho difícil falar o que sinto em relação às } \\
\text { pessoas }\end{array}$ \\
\hline
\end{tabular}


Fortes, T. R., Bordin, I. A. S., \& Semer, N. L. (2017). TAS-26 Adapted to Low-Educated Adults. ... continuation

\begin{tabular}{|c|c|c|c|}
\hline & $\begin{array}{l}\text { Original version } \\
\text { (Taylor et al., 1985) }\end{array}$ & $\begin{array}{l}\text { Pre-existing version } \\
\text { (Yoshida, 2000) }\end{array}$ & $\begin{array}{c}\text { Adapted version } \\
\text { (authors of this study, 2015) }\end{array}$ \\
\hline 23 & $\begin{array}{l}\text { People tell me to describe my feelings } \\
\text { more }\end{array}$ & $\begin{array}{l}\text { As pessoas falam para eu descrever mais } \\
\text { os meus sentimentos }\end{array}$ & $\begin{array}{l}\text { As pessoas me pedem para falar mais sobre os } \\
\text { meus sentimentos }\end{array}$ \\
\hline 24 & $\begin{array}{l}\text { One should look for deeper explana- } \\
\text { tions }\end{array}$ & $\begin{array}{l}\text { Deve-se procurar por explicações mais } \\
\text { profundas }\end{array}$ & $\begin{array}{l}\text { As pessoas deveriam procurar por explicações } \\
\text { mais profundas das coisas }\end{array}$ \\
\hline 25 & I don't know what's going on inside me & Não sei o que acontece dentro de mim & Eu não sei o que acontece dentro de mim \\
\hline 26 & I often don't know why I am angry & $\begin{array}{l}\text { Frequentemente eu não sei por que estou } \\
\text { com raiva }\end{array}$ & Muitas vezes não sei por que estou bravo \\
\hline
\end{tabular}

Table 3 highlights the differences between the original version of the TAS-26 (Taylor et al., 1985) and the back translation of the final version of the Brazilian TAS-26 adapted for use with adults with low levels of education. For example, the term "describe" was replaced by "talk", since describing feelings or problems implies talking about them and "talk" is easier to understand. Likewise, the term "analyze" was replaced by "think about", while the term "identify" when referring to feelings was replaced by "know what they are". These modifications were made without affecting the content of the items in view of the need to adopt a more colloquial style of language to facilitate understanding.

Table 3

Original Version of TAS-26 and Back-Translation of the Final Adapted Brazilian Version

\begin{tabular}{|c|c|c|}
\hline & Original version (Taylor et al., 1985) & Back-translation of the final adapted Brazilian version \\
\hline 1 & When I cry I always know why & When I cry, I always know why \\
\hline 2 & Daydreaming is a waste of time & Daydreaming is a waste of time \\
\hline 3 & I wish I were not so shy & I would like to be less shy \\
\hline 4 & I am often confused about what emotion I am feeling & I am often confused about what emotion I am feeling \\
\hline 5 & I often daydream about the future & I often daydream about my future \\
\hline 6 & I seem to make friends as easily as others do & I make friends as easily as other people \\
\hline 7 & $\begin{array}{l}\text { Knowing the answers to problems is more important than } \\
\text { knowing the reasons for the answers }\end{array}$ & $\begin{array}{l}\text { When I have a problem, I usually find a solution without thinking } \\
\text { too much about the reasons for the solution }\end{array}$ \\
\hline 8 & It is difficult for me to find the right words for my feelings & It is difficult for me to find the right words to express my feelings \\
\hline 9 & I like to let people know where I stand on things & I like to let people know what I think about things \\
\hline 10 & I have physical sensations that even doctors don't understand & Not even doctors understand what I feel in my body \\
\hline 11 & $\begin{array}{l}\text { It's not enough for me that something gets the job done; I need } \\
\text { to know why and how it works }\end{array}$ & If something gets a task done, I need to understand how it works \\
\hline 12 & I'm able to describe my feelings easily & I can talk easily about my feelings \\
\hline 13 & I prefer to analyze problems rather than just describe them & I prefer to think about my problems instead of just talking about them \\
\hline 14 & When I am upset, I don't know if I am sad, frightened, or angry & When I am upset, I don't know whether I am sad, frightened or angry \\
\hline 15 & I use my imagination a great deal & I use my imagination a lot \\
\hline 16 & I spend much time daydreaming whenever I have nothing else to do & I spend a lot of time daydreaming whenever I have nothing to do \\
\hline 17 & I am often puzzled by sensations in my body & I am often confused by the sensations in my body \\
\hline 18 & I daydream rarely & I rarely daydream \\
\hline 19 & $\begin{array}{l}\text { I prefer to just let things happen rather than to understand why } \\
\text { they turned out that way }\end{array}$ & $\begin{array}{l}\text { When things happen, I don't try to understand why they happened } \\
\text { the way they did }\end{array}$ \\
\hline 20 & I have feelings that I can't quite identify & I have feelings that I don't know what they are \\
\hline 21 & Being in touch with emotions is essential & It is very important to be in touch with your emotions \\
\hline 22 & I find it hard to describe how I feel about people & I find it difficult to say what I feel about people \\
\hline 23 & People tell me to describe my feelings more & People ask me to talk about my feelings more \\
\hline 24 & One should look for deeper explanations & People should look for deeper explanations about things \\
\hline 25 & I don't know what's going on inside me & I don't know what is happening inside of me \\
\hline 26 & I often don't know why I am angry & I often don't know why I am angry \\
\hline
\end{tabular}




\section{Internal consistency of the adapted version of the TAS-26}

The findings showed the presence of Factor 1 of the alexithymia construct - difficulties in identifying feelings and distinguishing them from bodily sensations (DIF), comprising items $1,3,4,8,10,14,17,20,22,23,25$, and 26 of the TAS26. This same factor was also observed using the original ver- sion of the TAS-26 in English (Taylor et al., 1988) and the Brazilian version of the TAS-26 developed by Yoshida.

The Brazilian version of the TAS-26 adapted for use with adults with low levels of education demonstrated adequate internal consistency considering the scores for both the overall scale and the Factor 1 subscale (Cronbach's alpha = around 0.70 or more) (Table 4 ).

Table 4

Internal Consistency of TAS-26 (Total Sample, $n=180)$ - Total Score and Factor 1

\begin{tabular}{ccc}
\hline TAS-26 & Number of items & Cronbach's alpha \\
\hline Total score & 26 & 0.647 \\
Factor 1 (DIF) & 7 & 0.869 \\
\hline
\end{tabular}

Note. DIF = Difficulty identifying feelings and distinguishing between feelings and bodily sensations.

\section{Discussion}

\section{Internal consistency of the TAS-26: Overall Scale}

In the first study carried out by the creators of original version of the TAS-26 with a sample of undergraduate psychology students the instrument demonstrated good internal consistency (Chronbach's alpha $=0.79$ for the overall scale) (Taylor et al., 1985). Two other studies, one conducted by Parker, Bagby and Taylor (1989) with social science students from a university in Canada to obtain a better understanding of the association between alexithymia and other personality traits and another undertaken by Motan \& Gençöz (2007) demonstrated similar levels of internal consistency (Chronbach's alpha $=0.72$ and 0.70 , respectively).

A study conducted by Yoshida (2000) to validate the TAS-26 for use with the Brazilian population based on self-reporting by a sample of 581 university students found a Chronbach's alpha of 0.71 for the overall scale, which is similar to that found by for the Uruguayan version of the TAS-26 (Chronbach's alpha $=0.78$ ) also using a sample of university students and consistent with the original version in English (Rodrigo, Lusiardo, \& Normey, 1989). Another study conducted by Yoshida (2007) in Brazil using a clinical sample of 294 patients admitted to a general public hospital in the State of São Paulo (who received help to complete the questionnaire) found a Chronbach's alpha of 0.72 .

Despite similarities in the internal consistency of the TAS-26 in the Brazilian studies mentioned above, the factor analyses yielded different results. The study involving university students identified four factors (ability to identify and describe feelings and distinguish between feelings and bodily sensations; daydreaming; externally-oriented thinking; and ability to communicate feelings to other people) (Yoshida, 2000), while the study undertaken with hospital patients identified three factors: ability to identify and describe feelings and distinguish them from bodily (impaired in individuals with alexithymia); concrete style of thinking based on reality, impoverished fantasy and imagination (operative thought, expressing features consistent with alexithymia); and ability to express affection and fantasies (impaired in individuals with alexithymia) (Yoshida, 2007). The results of factor analysis in the study with university students showed four factors that were consistent with the Spanish version of the TAS-26, which were in turn concordant with the English version (Yoshida, 2000). The number of factors and the items that comprised these factors differed between the clinical sample and the sample of university students. In light of these differences, doubt remains as to whether an instrument that has a sufficient level of adequacy for use with university students would be adequately understood by public health service users. These findings emphasize the importance of adapting the TAS-26 for use with people with low levels of education to ensure that results do not differ due to difficulties in understanding the content of the items of the TAS-26.

Despite the fact that the value of the alpha coefficient found by the present study is lower than those observed by previous studies (0.65 compared to $0.70-0.79)$, based on the criteria developed by Wiethaeuper et al. (2005), which consider values above 0.60 to be satisfactory, the TAS-26 adapted for use with people with low levels of education demonstrated satisfactory internal consistency.

\section{Internal consistency of the TAS-26: the DIF Factor}

The present study showed a Chronbach's alpha of 0.87 for the factor 1 subscale of the TAS-26 associated with difficulties in identifying feelings and distinguishing them from bodily sensations (DIF). Previous studies that have measured the internal consistency of the DIF factor subscale using samples of undergraduate psychology students (Taylor et al., 1985) and university students in Turkey (Motan \& Gençöz, 2007) found Chronbach's alpha values of 0.83 and 0.80 , respectively. Since the Factor 1 subscale of the TAS-26 is composed of the same items as the Factor 1 subscale of the TAS-20 (revised version of the TAS-26), our results may be compared with those obtained by researchers who examined the internal consistency of the Factor 1 subscale of the TAS20. It is important to note that the use of it was not possible to produce an adapted version of the Brazilian TAS-20 since the 
publication of its items were not authorized by the authors; while the original version of the TAS-26 is available in the public domain.

A study conducted to validate the revised Spanish version of the TAS-20 used this instrument on 221 multiple sclerosis patients receiving treatment in a university hospital in Spain and obtained a Chronbach's alpha of 0.87 for the Factor 1 subscale (Fernández-Jiménez et al., 2013), which is identical to that of the present study. Studies that applied the TAS20 in samples from different countries obtained Chronbach's alpha for the Factor 1 subscale that were similar to or lower than that of the present study. Values equal to or greater than 0.80 were obtained using the following samples: asymptomatic adults $(\alpha=0.80)$ (Praceres et al., 2000); the general population in Portugal $(\alpha=0.83)$ (Praceres et al., 2000); psychiatric patients $(\alpha=0.81)$ (Bagby, Parker, et al., 1994); and Korean adolescents without any complaint $(\alpha=0.85)$ (Seo, Chung, Rim, \& Jeong, 2009). Values under 0.80 were found using the following samples: a Japanese clinical sample $(\alpha=$ 0.79); Polish students $(\alpha=0.2)$; Peruvian students $(\alpha=0.67)$ (Taylor et al., 2003b); various samples of Canadian university students ( $\alpha=$ around 0.78$)$ (Bagby, Taylor, et al., 1994); healthy Austrian adults $(\alpha=0.79)$ (Bach, Bach, \& de Zwaan, 1996); and psychosomatic patients $(\alpha=0.72)$ (Bach et al., 1996).

The fact that the level of internal consistency of the DIF factor subscale is generally greater than that of the overall scale reflects the particularly strong association between this factor and the alexithymia construct, as shown by the high levels of reliability observed by various studies (Taylor et al., 2003b). The difficulties in identifying feelings factor is therefore a central component of the alexithymia construct construct, and the DIF factor is an indicator of these difficulties in both clinical and nonclinical samples.

One of the limitations of this study is the fact that a cognitive assessment of study participants was not performed, given that there may be some degree of decline in cognitive capacity with increasing age and this can affect both the ability to understand the content of the items of the TAS-26 and perceptions of feelings and emotions. Future studies should address this question.

The findings of this study show that the Brazilian version of the 26-item Toronto Alexithymia Scale (TAS-26) adapted for use with adults with a low level of education (the authors of this article, 2015) demonstrates adequate internal consistency (Chronbach's alpha $=$ around 0.70 or greater) both for the overall scale and Factor 1 subscale (difficulties in identifying feelings and distinguishing them from bodily sensations), thus demonstrating the adequacy of this instrument for use with this population group when administered through individual interviews.

\section{References}

Bach, M., Bach, D., \& de Zwaan, M. (1996). Independency of alexithymia and somatization: A factor analytic study. Psychosomatics, 37(5), 451-458. doi:10.1016/S00333182(96)71533-5
Bagby, R. M., Parker, J. D. A., \& Taylor, G. J. (1994). The twenty-item Toronto Alexithymia Scale - I. Item selection and cross-validation of the factor structure. Journal of Psychosomatic Research, 38(1), 23-32. doi:10.1016/0022-3999(94)90005-1

Bagby, R. M., Taylor, G. J., \& Parker, J. D. A. (1994). The twenty-item Toronto Alexithymia Scale - II. Convergent, discriminant, and concurrent validity. Journal Psychosomatic Research, 38(1), 33-40. doi:10.1016/ 0022-3999(94)90006-X

Cacioppo, J. T., \& Petty, R. E. (1982). The need for cognition. Journal of Personality, 42(1), 116-131. doi:10.1037/00223514.42.1.116

Carneiro, B. V., \& Yoshida, E. M. P. (2009). Alexitimia: Uma revisão de conceito.[A review of Alexithymia Concept] Psicologia: Teoria e Pesquisa, 25(1), 103-108. doi:10.1590/S0102-37722009000100012

Cox, B. J., Kuch, K., Parker, J. D. A., Shulman, I. D., \& Evans, R. J. (1994). Alexithymia in somatoform disorder patients with chronic pain. Journal of Psychosomatic Research, 38(6), 523-527. doi:10.1016/0022-3999(94)90049-3.

Di Tella, M., \& Castelli, L. (2016). Alexithymia in chronic pain disorders. Current Rheumatology Reports, 18(7), 41. doi:10.1007/s11926-016-0592-x

Fernández-Jiménez, E., San-Gregorio, M. A. P., Taylor, G. J., Bagby, R. M., Ayearst, L. I., \& Izquierdo, G. (2013). Psychometric properties of a revised Spanish 20-item Toronto Alexithymia Scale adaptation in multiple sclerosis patients. International Journal of Clinical Health Psychology, 13(3), 226-234. doi:10.1016/S1697-2600(13)70027-9

Garner, D. M., Olmsted, M. P., \& Polivy, J. (1983). Development and validation of a multidimensional eating disorder inventory for anorexia nervosa and bulimia. International Journal of Eating Disorders, 2(2), 15-34. doi:10.1002/ 1098-108X(198321)2:23.0.CO;2-6

George, D., \& Mallery, P. (2003). SPSS for Windows step by step: A simple guide and reference, 11.0 update (4th ed.). Boston, MA: Allyn \& Bacon.

Hintistan, S., Cilingir, D., \& Birinci, N. (2013). Alexithymia among elderly patients with diabetes. Pakistan Journal of Medical Sciences, 29(6), 1344-1348. doi:10.12669/ pjms.296.2159

Instituto Brasileiro de Geografia e Estatística. (2016). Brasil em sintese: Educação. Retrieved from http://brasilemsintese.ibge.gov.br/educacao.html

Kusevic, Z., Civljak, M., Rukavina, T. V., Babic, G., Loncar, M., Cusa, B. V., \& Gregurek, R. (2013). The connection between alexithymia and somatic morbidity in a population of combat veterans with chronic PTSD. Acta Informatica Medica, 21(1), 7-11. doi:10.5455/aim.2013.21.7-11

Lumley, M. A., Stettner, L., \& Wehmer, F. (1996). How are alexithymia and physical illness linked? A review and critique of pathways. Journal of Psychosomatic Research, 41(6), 505-518. doi:10.1016/S0022-3999(96)00222-X 
Marchesi, C., Giaracuni, G., Paraggio, C., Ossola, P., Tonna, M., \& De Panfilis, C. (2013). Pre-morbid alexithymia in panic disorder: A cohort study. Psychiatry Research, 215(1), 141-145. doi:10.1016/j.psychres.2013.10.030

Motan, I., \& Gençöz, T. (2007). The relationship between the dimensions of alexithymia and the intensity of depression and anxiety. Türk Psikiyatri Dergisi, 18(4), 333-343.

Onor, M. L., Trevisiol, M., Spano, M., Aguglia, E., \& Paradiso, S. (2010). Alexithymia and aging: A neuropsychological perspective. Journal of Nervous and Mental Disease, 198(12), 891-895. doi:10.1097/NMD.0b013e3181fe743e

Parker, J. D. A., Bagby, R. M., \& Taylor, G. J. (1989). Toronto Alexithymia Scale, EPQ and self-report measures of somatic complaints. Personality and Individual Differences, 10(6), 599-604. doi:10.1016/0191-8869(89)90219-5

Pirlot, G., \& Corcos, M. (2012). Understanding alexithymia within a psychoanalytical framework. International Journal of Psycho-analysis, 93(6), 1403-1425. doi:10.1111/j.1745-8315.2012.00657.x

Praceres, N., Parker, J. D. A., \& Taylor, G. J. (2000). Adaptação portuguesa da Escala de Alexitimia de Toronto de 20 itens (TAS-20).[Portuguese Adaptation of the 20item Toronto Alexithymia Scale (TAS-20)] RIDEP, 9(1), 9-21. Retrieved from http://www.aidep.org/03_ridep/R09/ R091.pdf

Rodrigo, G., Lusiardo, M., \& Normey, L. (1989). Alexithymia: Reliability and validity of the Spanish version of the Toronto Alexithymia Scale. Psychotherapy and Psychosomatics, 51(3), 162-168. doi:10.1159/000288151

Saariaho, A. S., Saariaho, T. H., Mattila, A. K., Joukamaa, M. I., \& Karukivi, M. (2016). The role of alexithymia: An 8 -year follow-up study of chronic pain patients. Comprehensive Psychiatry, 69, 145-154. doi:10.1016/j.comppsych.2016.05.015

Sayar, K., Kirmayer, L. J., \& Taillefer, S. S. (2004). Predictors of somatic symptoms in depressive disorder. General Hospital Psychiatry, 25(2), 108-114. doi:10.1016/S01638343(02)00277-3

Semer, N. L. (2012). Dor e sofrimento psíquico: Uma reflexão sobre as relações e repercussões corpo e mente [Pain and Psychic Suffering: A Reflection on the Relationships and Repercussions of Body and Mind]. Revista Brasileira de Psicanálise, 46(3), 188-199.

Seo, S. S., Chung, U.-S., Rim, H. D., \& Jeong, S. H. (2009). Reliability and validity of the 20-item Toronto Alexithymia Scale in Korean adolescents. Psychiatry Investigation, 6(3), 175-179. doi:10.4306/pi.2009.6.3.173

Silva, H., Freitas, J., Moreira, S., Santos, A., \& Almeida, V. (2016). Alexithymia and psychopathology in patients with acute myocardial infarction. Acta Cardiologica, 71(2), 213-220. doi:10.2143/AC.71.2.3141852
Sfineos, P. E. (1973). The prevalence of 'alexithimic' characteristics in psychosomatic patients. Psychotherapy and Psychosomatics, 22(2), 255-262.

Steinweg, D. L., Dallas, A. P., \& Rea, W. S. (2011). Fibromyalgia: Unspeakable suffering, a prevalence study of alexithymia. Psychosomatics, 52(3), 255-262. doi:10.1016/j. psym.2010.12.022

Swart, M., Kortekaas, R., \& Aleman, A. (2009). Dealing with feelings: Characterization of trait alexithymia on emotion regulation strategies and cognitive-emotional processing. PLoS One, 4(6), e5751. doi:10.1371/journal. pone. 0005751

Taylor, G. J., Bagby, R. M., \& Parker, J. D. A. (2003a). Disorders of affect regulation: Alexithymia in medical and psychiatry illness. Cambridge, United Kingdom: Cambridge University Press.

Taylor, G. J., Bagby, R. M., \& Parker, J. D. A. (2003b). The 20Item Toronto Alexithymia Scale IV: Reliability and factorial validity in different languages and cultures. Journal of Psychosomatic Research, 55(3), 277-283. doi:10.1016/ S0022-3999(02)00601-3

Taylor, G. J., Bagby, R. M., \& Parker, J. D. A. (2016). What's in the name 'alexithymia'? A commentary on "Affective agnosia: Expansion of the alexithymia construct and a new opportunity to integrate and extend Freud's legacy". Neuroscience and Biobehavioral Reviews, 68, 1006-20. doi:10.1016/j.neubiorev.2016.05.025

Taylor, G. J., Bagby, R. M., Ryan, D. P., Parker, J. D. A., Doody, K. F., \& Keefe, P. (1988). Criterion validity of the Toronto Alexithymia Scale. Psychosomatic Medicine, 50(5), 500-509. doi:10.1097/00006842-198809000-00006

Taylor, G. J., Ryan, D., \& Bagby, R. M. (1985). Toward the development of a new Self-Report Alexithymia Scale. Psychotherapy and Psychosomatics, 44(4), 191-199. doi:10.1159/000287912

van Middendorp, H., Lumley, M. A., Jacobs, J. W. G., van Doornen, L. J. P., Bijlsma, J. W. J., \& Geenen, R. (2008). Emotions and emotional approach and avoidance strategies in fibromyalgia. Journal of Psychosomatic Research, 64(2), 159-167. doi:10.1016/j.jpsychores.2007.08.009

Wiethaeuper, D., Balbinotti, M. A. A., Pelisoli, C., \& Barbosa, M. L. L. (2005). Estudos da consistência interna e fatorial confirmatório da Escala Toronto de Alexitimia - 20 (ETA - 20) [Reliability and confirmatory factorial analysis of the Toronto Alexithymia Scale-20 (TAS-20) with Brazilian students]. Interamerican Journal Psychology, 39(2), 221-230. Retrieved from http://www.psicorip.org/Resumos/PerP/RIP/RIP036a0/RIP03924.pdf

Winckers, A. N., Mackenbach, J. D., Compernolle, S., Nicolaou, M., van der Ploeg, H. P., De Bourdeaudhuij, I., ... Lakerveld, J. (2015). Educational differences in the validity of self-reported physical activity. BMC Public Health, 15, 1299. doi:10.1186/s12889-015-2656-7 
Yoshida, E. M. P. (2000). Toronto Alexithymia Scale-TAS: Precisão e validade da versão em português.[Toronto Alexithymia Scale-TAS: Reliability and validity of the portuguese version] Psicologia: Teoria e Prática, 2(1), 59-74. Retrieved from http://editorarevistas.mackenzie.br/index. $\mathrm{php} / \mathrm{ptp} /$ article/viewFile/1119/828

Yoshida, E. M. P. (2007). Validade da versão em português da Toronto Alexithymia Scale em amostra clínica [Validity of the portuguese version of the Toronto Alexithymia Scale-TAS in a sample of inpatients]. Psicologia: Reflexão e Crítica, 20(3), 389-396. doi:10.1590/S010279722007000300006

Tatiana Roccato Fortes holds a Master's Degree in Science from Universidade Federal de São Paulo.

Isabel Altenfelder Santos Bordin is a Senior Researcher at the Universidade Federal de São Paulo.

Norma Lottenberg Semer is an Affiliated Professor at the Universidade Federal de São Paulo.

Received: June 6, 2016

1st Revision: Nov. 7, 2016

Approved: Dec. 2, 2016

How to cite this article:

Fortes, T. R., Bordin, I. A. S., \& Semer, N. L. (2017). Toronto Alexithymia Scale: Adaptation of the Brazilian version to low-educated adults. Paidéia (Ribeirão Preto), 27(67), 100-109. doi: 10.1590/1982-43272767201712 